Article

\title{
Creating Social Safeguards for REDD+: Lessons Learned from Benefit Sharing Mechanisms in Vietnam
}

\author{
Mucahid Mustafa Bayrak ${ }^{1, *}$, Tran Nam Tu ${ }^{2, \dagger}$ and Lawal Mohammed Marafa ${ }^{1, \dagger}$ \\ 1 Department of Geography and Resource Management, The Chinese University of Hong Kong, \\ Shatin, N.T., Hong Kong, China; E-Mail: 1mmarafa@cuhk.edu.hk \\ 2 Center for Scientific and Technology Incubations and Transfers, Hue University, \\ Hue City, Vietnam; E-Mail: trannamtu@gmail.com \\ $\dagger$ These authors contributed equally to this work. \\ * Author to whom correspondence should be addressed; E-Mail: mmbayrak@cuhk.edu.hk; \\ Tel.: +852-9525-0754; Fax: +852-2603-5006.
}

Received: 3 June 2014; in revised form: 31 July 2014 / Accepted: 8 August 2014 /

Published: 22 August 2014

\begin{abstract}
Currently, many studies on benefit sharing mechanisms (BSM) and the Reducing Emissions from Deforestation and Forest Degradation programme (REDD+) focus on poverty alleviation and livelihood development. However, relatively few studies incorporate an integrated livelihood framework. This study employs the sustainable livelihoods framework to assess the impact of BSM in Vietnam. The lessons learned could be used in creating social safeguards for REDD+. The communities in Central Vietnam involved in BSM were impacted by the programme on various dimensions. These dimensions, expressed in different types of capital, are interconnected and contribute to a person's well-being. While the communities have restricted access to their natural forests, they benefited in terms of income diversification, knowledge improvement and network expansion. On the other hand, they faced food insecurity, they were more vulnerable to natural hazards, and their human, social and cultural capital faced risk of deterioration.
\end{abstract}

Keywords: sustainable livelihoods approach; REDD+; benefit sharing mechanisms, forest management in Vietnam; social safeguards 


\section{Introduction}

There are two schools of thoughts on Reducing Emissions from Deforestation and Forest Degradation programme (REDD + ) and livelihoods: The first one argues that REDD + should solely focus on climate change mitigation but poor households should not be negatively affected, while the second one argues that REDD+ should be pro-poor in order to succeed [1,2]. To et al. [3] stress that it is important that at least the negative socio-economic impacts of REDD + are minimized, that REDD + benefits are equitably shared, and that there is an adequate participation and consultation of local communities in the planning and execution of REDD+ projects. Therefore, in order to minimize the negative impacts of REDD+, a balance needs to be found between equal benefit sharing, meaningful community participation, and livelihood diversification strategies. REDD + will most likely not alleviate poverty, but it could allow local communities to diversify their income and livelihood strategies [1]. Both schools of thoughts agree that social safeguards need to be created that at least prevent REDD + of negatively affecting the communities' livelihoods.

Vietnam, being a REDD+ pilot country for the United Nations Collaborative Programme on Reducing Emissions from Deforestation and Forest Degradation in Developing Countries, the Forest Carbon Partnership Facility of the World Bank, and various non-governmental organizations (NGOs), have already implemented various payments for environmental services (PES), benefit sharing mechanisms (BSM), and community forestry (CF) projects and programmes throughout the country [4]. Most likely, the lessons learned from these projects will be valuable for REDD+ implementation. While many studies on REDD+, PES and BSM have focused on livelihood improvement or poverty alleviation [2,5,6], relatively few studies have incorporated a comprehensive framework on livelihood development (e.g., [7-9]].

The main purpose of this study is to apply the sustainable livelihoods approach [10] to identify the livelihood impacts of benefit sharing mechanisms in Vietnam. Whereas Mahanty et al. [8] used the sustainable livelihoods approach in assessing the livelihood impact of PES on local communities on meta-level, this study uses an in-depth analysis of two case-studies. Two communes in Central Vietnam with BSM in forest protection have been chosen for this research. Through qualitative research and focus groups discussions, the (potential) impacts of BSM on communities' livelihoods will be assessed. The lessons learned from BSM, could provide valuable lessons and insights for REDD+ implementation. Especially, incorporating the sustainable livelihoods approach in the current REDD+ discourse could allow policy makers and implementers of REDD + to create stronger safeguards in minimizing the negative effects of REDD+ on livelihoods.

This paper is organized as follows. Section 2 provides an introduction to REDD+, and the progress of REDD+ in Vietnam. Section 3 discusses the theoretical framework of this study. What exactly is the sustainable livelihoods approach and how could it be incorporated in creating social safeguards for REDD+? Section 4 deals with the research context and methodology. Section 5 identifies the (potential) livelihood impacts of BSM in the research communes. Section 6 is the discussion which provides a comprehensive livelihood framework to avoid the negative impacts of BSM and REDD+ on communities' livelihoods, as well as recommendations for creating social safeguards for REDD+. Finally, Section 7 is the conclusion. 


\section{An Introduction to REDD+}

The Reducing Emissions from Deforestation and Forest Degradation programme or in short REDD+ is a global initiative which recognizes the significance of forests in reversing and mitigating global climate change. The global initiative was introduced in 2007 during the 13th Conference of the Parties to the UNFCCC in Bali after it was proposed by the Coalition for Rainforest Nations, a group of countries led by Papua New Guinea. The basic premise of REDD+ is straightforward: Developed countries will pay developing countries for conserving their forests through carbon credits, since forests, and especially tropical forests, are big carbon sinks. While previous global climate negotiations have solely focused on avoided deforestation (RED) and avoided forest degradation (REDD), REDD+ also includes the sustainable management of forests, enhancements of carbon stocks and improved forest protection. Currently, the two main multilateral readiness platforms for REDD + are the United Nations Collaborative Programme on Reducing Emissions from Deforestation and Forest Degradation in Developing Countries (UN-REDD) and the Forest Carbon Partnership Facility (FCPF) of the World Bank. Furthermore, various international and non-governmental organizations, as well as governments and private actors are involved in REDD+ readiness activities or pilot projects. However, so far, no country is operating REDD+ on a national level yet $[11,12]$.

Vietnam entered Phase II of UN-REDD in December 2012. The steps which Vietnam already has undertaken since 2009 to be REDD+ ready include the establishment of a National REDD+ Action Programme, Network and Steering Committee. Vietnam has also been mainstreaming REDD+ into socio-economic development plans and strategies, and requested its Provincial People's Committees to establish inter-agency REDD+ Steering Committee at provincial level. Furthermore, Vietnam has piloted REDD+ in Lam Dong province, and it has launched many analytical studies in order to increase its REDD+ effectiveness [13]. Besides the government of Vietnam and multilateral agencies, various NGO's, both domestic and international, are involved in REDD+ pilot projects. At the moment, there are around 24 pilot REDD+ projects in Vietnam. Besides REDD+, domestic and international organizations have also implemented projects and programmes on BSM, PES and CF in various regions of Vietnam.

\section{REDD+ and the Sustainable Livelihoods Approach}

\subsection{The Sustainable Livelihoods Approach}

Within the REDD+ debate the term "sustainable livelihood development" is often mentioned. However, sustainable livelihood development is not just a linear process which is easily measurable by simple indicators, such as malnutrition rates, poverty levels, or the availability of employment or natural resources [14]. A particular context (policy, politics, history, ecology, socio-economic conditions, culture, and so on), and the combination of livelihood resources (different types of capital) allow, influence and, sometimes, force local people to create particular livelihood strategies which result in certain outcomes. Institutional processes (both formal and informal) often play an essential role in livelihood development [15]. REDD + is mainly channeled through formal institutional processes and could therefore influence the livelihood development of the involved communities. 
A livelihood, according to Chambers and Conway [10], comprises "capabilities", tangible (stores and resources) and intangible assets (claims and access). Sen [16] argues that development means freedom. People have "functionings", valuable activities and states that become a person's wellbeing; "capabilities", the various combinations of functionings (beings and doings) that the person can achieve; and "agency", the ability to pursue goals that one has reason to value. Livelihood capabilities also refer to one's ability to cope with stress and shocks, and to make use of different livelihood opportunities [10].

An approach which could encompass the various complex dimensions of a livelihood is the sustainable livelihoods approach. The sustainable livelihoods approach involves political, social, cultural and ecological aspects [17]. Therefore, this approach entails different types of interconnected capital, which could contribute to someone's well-being. These types of capital are: natural, physical, financial, human, social and cultural (see Table 1). A sustainable livelihoods approach looks at the availability of these types of capital in a particular context, and on one's judgment of what compromises well-being and happiness $[10,15,17-20]$. The different types of capital cannot be seen as static. For example, the dynamic nature of the different types of capital could result in long-term co-benefits of forest protection, as opposed to the lesser short-term benefits of forest exploitation. In conclusion, the sustainable livelihoods approach encompasses three aspects: capability, equity and sustainability [10]. It is therefore a multi-faceted, interconnected, normative, dynamic, and holistic approach to sustainable livelihood development.

Table 1. Different types of capital. Sources: [15,18-20].

\begin{tabular}{cl}
\hline Type of Capital & \multicolumn{1}{c}{ Definition } \\
\hline Natural & $\begin{array}{l}\text { Natural resource stocks (forest, soil, water, etc.) and environmental services } \\
\text { (watershed protection, water supply, etc.). }\end{array}$ \\
\hline Physical & Tools, technology, infrastructure and the output of the production of natural capital. \\
\hline Financial & Cash, credit, savings, development assistance, and subsidies. \\
\hline Human & $\begin{array}{l}\text { Scientific, technological and customary knowledge, skills, education, health, } \\
\text { and manpower. }\end{array}$ \\
\hline Social & Shared values and norms, trust, networks, formal and customary rules and laws. \\
\hline Cultural & Habits, customs, dispositions, religion, and language. \\
\hline
\end{tabular}

\subsection{Applying the Sustainable Livelihoods Approach to REDD+}

The "do-no-harm" and the "pro-poor" schools of thought on REDD+ both agree that REDD+ should not negatively affect the livelihoods of the affected forest-dependent communities. Since it has been acknowledged that REDD+ has the potential to influence the livelihoods of these communities, the next step is to incorporate the sustainable livelihoods approach to REDD+.

Figure 1 (based on: IFAF [21]) applies the sustainable livelihoods approach to a REDD+ context. The central element in this model is the concept of Free, Prior, and Informed Consent (FPIC). FPIC is defined by UN-REDD and the World Bank [22] as:

"The collective right of indigenous peoples to participate in decision-making and to give or withhold their consent to activities affecting their lands, territories and resources or rights in general. Consent must be freely given, obtained prior to implementation of activities and 
be founded upon an understanding of the full range of issues implicated by the activity or decision in question; hence the formulation: free, prior and informed consent."

Figure 1. Applied REDD+ livelihoods model.

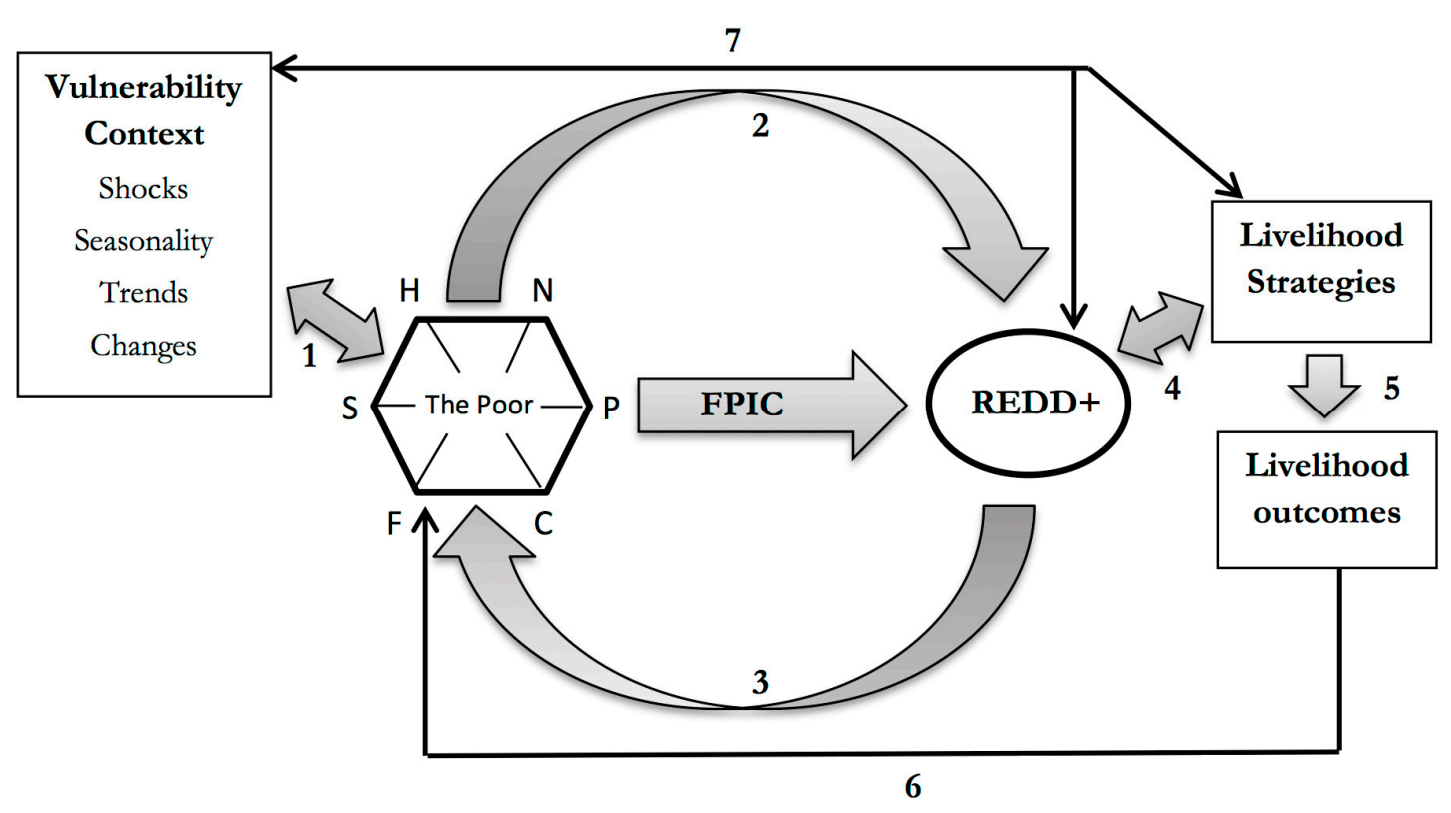

In theory, local communities are therefore able to have control over a REDD+ project. However, future studies need to reveal whether local communities and the poor in particular, really have that option and power. Both Leggett and Lovell [23], and Bolin and Tassa [24] state that the researched communities, in Papua New-Guinea and Tanzania respectively, involved in a REDD+ project, were mostly unaware of the project, and that only a privileged few villagers had knowledge about REDD+. In these cases there was no true FPIC in both communities, regardless of the FPIC activities which have been done. Therefore, the first step of creating social safeguards for REDD+ is effective and true FPIC.

The second step deals with the context. A particular socio-economic, political and environmental context influences the availability of capital of the poor, but the availability of capital may also influence the context (arrow 1 in Figure 1) - e.g., when natural resources are in a poor condition, a local community has more likely to deal with shocks such as flooding or drought. REDD+ needs to take the local context into account, even though it is now often being regarded as a blue print or a one-size-fits-all approach.

The availability of capital decides how REDD + should be implemented (arrow 2 in Figure 1). The UN-REDD programme and the FCPF [22], for example, consider whether a local or indigenous community has customary lands (natural capital), laws and customs (cultural capital), institutions (social capital) or knowledge systems (human capital) related to the targeted REDD+ forest. The type of forest is also important in implementing REDD +. The forests could be very rich in biodiversity and under no threat, the forests could be under threat, or the forests could be degraded already. Therefore, are communities rewarded for conservation, avoided deforestation, or reforestation [25]?

At the same time, REDD+ could also influence the availability on the various types of capital (arrow 3 in Figure 1). For example, REDD+ may undermine the decentralization of forest governance in developing countries or disturb the forestland tenure systems [26-29]. It may also exclude poor 
households from receiving benefits [23,24], increase food insecurity [30], or change the social and cultural capital of the host communities [31-33].

REDD+ influences the livelihood strategies of local communities and vice versa (arrow 4 in Figure 1). In a REDD+ scheme villagers are, for example, not able to cut trees for commercial purposes anymore, while this same scheme might also provide villagers new employment opportunities, such as reforestation activities and so on. The recognition and the need of creating alternative and viable livelihood strategies are of particular importance in creating social safeguards.

The livelihood strategies decide the livelihood outcomes (arrow 5 in Figure 1), in which the outcomes influence the availability and types of capital (arrow 6 in Figure 1). Reforestation activities could result in a higher forest density, a higher carbon sequestration and more biodiversity (natural capital). On the other hand, the context is crucial for the success of REDD + and the livelihood strategies (arrow 7 in Figure 1). Shocks such as natural hazards, which may or may not be caused by human induced climate change, could force villagers to resort to other livelihood strategies, and also determine whether a REDD+ project will be successful or not. Carbon is just temporarily stored in the forests. There is no guarantee that this stored carbon will not be emitted in the future because of economic destructive activities or natural hazards [11].

In conclusion, creating social safeguards for REDD+ starts with FPIC. Are the communities, being sufficiently informed about all the (potential) risks and opportunities involved, able to freely participate in a REDD+ project, and are they able to withdraw any time from the project or programme? The second step deals with the local context. Does REDD+ fit in the local context, and if so, how does REDD + take it into account? Third, which types of capital do the local communities have at their disposal? How do they make use of the forests and its products, and in what way does REDD+ prohibit and/or encourage them to accumulate a certain type of capital? The temporal aspect of the different types of capital is important to consider as well. The availability of capital both enables and constrains communities' livelihood strategies. Since REDD+ influences and is being influenced by the different types of capital, the next question deals with to what extent the livelihood strategies of local communities will be affected by REDD+. How do the changed livelihood strategies in its turn influence the availability of the different types of capital and livelihoods outcomes? Finally, how does REDD+ cope with external shocks? Natural hazards, which may or may not be induced by global climate change, could jeopardize a REDD+ project. Therefore, are there social safeguards in place which could deal with these external shocks?

\section{Research Context and Methodology}

\subsection{Forest Governance in Vietnam}

Forest governance in Vietnam has evolved from a laissez-faire attitude in the 1970s, and centralized top-down management focusing on forest exploitation in the 1980s, to decentralized forest management and conservation in the 1990s and 2000s. In 1991, Vietnam introduced the forestland allocation programme (FLA), which is a sub-programme of the Land Law of 1993 and the Law on Forest Protection and Development of 1994. The FLA programme is a forest devolution policy. Households, groups of households, and later on communities, were able to own natural and production forestland 
for long-term use through so called Red Books. The main rationale of the FLA programme is that if households and communities own forestland, they will have more incentives to invest in it or to preserve it. The FLA programme has been utilized to reach the objectives of the Five Million Hectares Reforestation programme (restoration of forest cover in Vietnam to $43 \%$ by 2010). Some forestland owners were involved in BSM and were paid for forest conservation, and received subsidies for tree planting. However, even though local people are now able to own forestland, it is still the State, backed by conservation agencies and NGOs, which stipulates how people should use the forests. Therefore, forest management in Vietnam is far from being truly "decentralized" [34-36].

\subsection{Research Communes}

Two communes have been chosen for this research: Huong Hiep commune in Da Krong district, Quang Tri province, and Thuong Nhat commune in Nam Dong district, Thua Thien-Hue province (see Figure 2).

Figure 2. Map of the research areas.

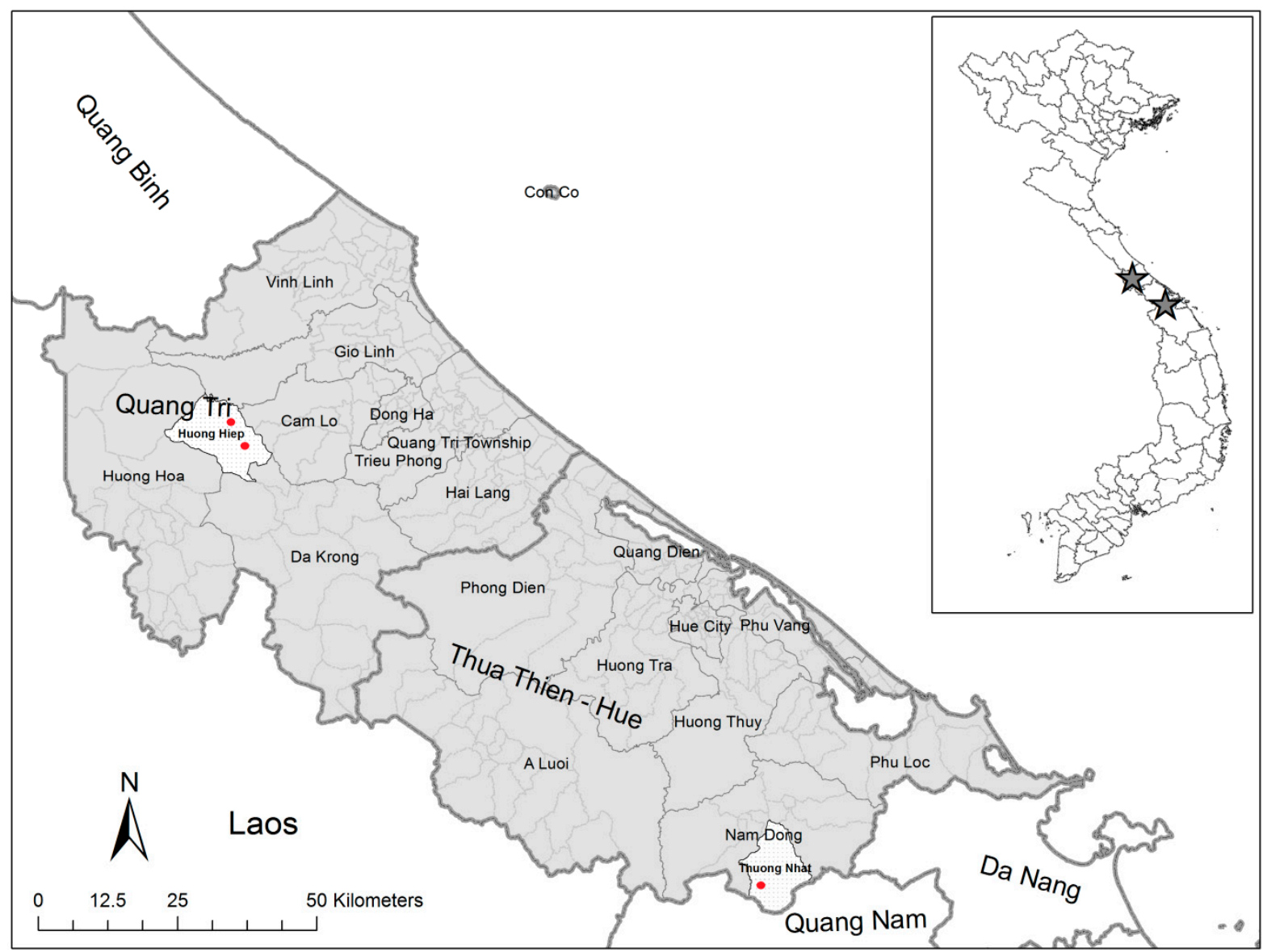

Note: Red dots are indications of the location of the villages.

Both communes almost exclusively consist of indigenous communities. Huong Hiep (4442 people in 2011) and Thuong Nhat (1853 people in 2013) are primarily inhabited by indigenous Van Kieu and $\mathrm{Co} \mathrm{Tu}$ people respectively. Local households in the communes are dependent on agriculture- both for subsistence and selling - agro-forestry (such as Acacia and rubber), and the natural forests. The local 
households practice wet-rice cultivation - with the size of land for cultivation ranging from $400 \mathrm{~m}^{2}$ to $5000 \mathrm{~m}^{2}$. Only in Huong Hiep, some households still practice shifting cultivation, even though it has been formally prohibited. In Thuong Nhat this practice has almost been completely banned.

The villagers of the communes use the natural forest for collecting non-timber forest products (NTFPs) and firewood, and they use its wood for housing and, to a lesser extent, selling. Some households are also involved in hunting and catching forest- and river-animals.

Main problems in the communes include: poverty, low education of the villagers, land-tenure problems, food insecurity, problems maintaining plantation forests, high vulnerability to natural hazards, and high degradation of the natural forests.

The Commune People Committee (CPC), the government entity on commune level, and the District People Committee (DPC), the government entity on district level, are primarily responsible for forest management and forestland allocation in the communes. However, the arrangements in each commune are different. In Huong Hiep, the CPC is responsible for allocating forestland (12,357 ha) to households, but so far no natural forestland (1718 ha) has been allocated yet. Instead, the CPC has selected some households to protect and monitor the natural forests for a fee. In Thuong Nhat, a part of the forestland (11,377 ha) belongs to Bach Ma National Park (7701 ha) and a part (2755 ha) belongs to the CPC. The CPC is responsible for allocating natural forestland to the communities of its villages - of which 987.5 ha of natural forestland has already been allocated.

\subsection{Research Villages and Methodology}

One village in Thuong Nhat and two villages in Huong Hiep have been visited for this research. Table 2 displays the background information of the villages, and the methodology and research methods which have been used for this study.

Table 2. The research villages and methodology.

\begin{tabular}{|c|c|c|}
\hline Locat & Main Characteristics & Methodology and Research Methods \\
\hline $\begin{array}{l}\text { Ha Bac and } \\
\text { Phu An village, } \\
\text { Huong Hiep } \\
\text { commune, } \\
\text { Da Krong district, } \\
\text { Quang Tri province }\end{array}$ & $\begin{array}{l}\text { Phu An consists of } 116 \text { households. } \\
\text { Forestland which belongs to the village } \\
\text { consists of plantation forests ( } 50 \text { ha), and } \\
\text { natural forests ( } 120 \text { ha). } \\
\text { Ha Bac consists of } 80 \text { households. Forest } \\
\text { land which belongs to the village consists } \\
\text { of plantation forests ( } 250 \text { ha), and natural } \\
\text { forests ( } 275 \text { ha). }\end{array}$ & $\begin{array}{l}\text { Semi-structured interviews with the forest } \\
\text { commune ranger }(N=1) \text {, village patriarch } \\
(N=1) \text {, village headmen }(N=2) \text { and local } \\
\text { households }(N=6) \text {. Focus group discussions } \\
\text { with community forest management boards } \\
\text { of both villages }(N=2) \text {. The research } \\
\text { activities have been conducted in June and } \\
\text { July } 2012 \text {. }\end{array}$ \\
\hline $\begin{array}{l}\text { Village no. } 6 \text {, } \\
\text { Thuong Nhat } \\
\text { commune, Nam } \\
\text { Dong district, Thua } \\
\text { Thien-Hue province }\end{array}$ & $\begin{array}{l}\text { Village no. } 6 \text { consists of } 74 \text { households. } \\
\text { Besides rice cultivation ( } 2.5 \text { ha), villagers } \\
\text { depend on Acacia ( } 35 \text { ha) and rubber } \\
\text { plantations ( } 30 \text { ha). Village no.6's } \\
\text { community forest covers an area of } 88.8 \text { ha } \\
\text { and the villagers have access to } 1100 \text { ha of } \\
\text { natural forest in BNMP. }\end{array}$ & $\begin{array}{l}\text { Semi-structured interviews with local } \\
\text { households }(N=3) \text { and the village headman } \\
(N=1) \text {. Focus group discussions with the } \\
\text { commune chairman, forest ranger and police } \\
\text { officer }(N=1) \text {, and the community forest } \\
\text { management board and local households of } \\
\text { village no. } 6(N=1) \text {. The research activities } \\
\text { have been conducted in May and June } 2013 \text {. }\end{array}$ \\
\hline
\end{tabular}




\section{Benefit Sharing in Huong Hiep and Thuong Nhat}

\subsection{Benefit Sharing Mechanisms in Huong Hiep, Da Krong District}

Da Krong district is in charge of implementing policies on benefit sharing in forest protection in its communes. The district is furthermore responsible for demarcating and classifying the forests. Huong Hiep commune formally allocates forestland to individual households, and decides which villages are eligible to receive financial incentives of natural forest protection. While the local people in the commune already owned Red Books for plantation forests, the natural forests has yet to be allocated to households or communities. According to the community forest management boards and the forest commune ranger, each village in Huong Hiep has a community forestry management board (CFMB) in which the village headman, the lowest government entity, is in charge of the board. Under district plan 38A, few individual households belonging to the CFMB are contracted to protect the natural forests belonging to their village for an amount of 200,000 VND per hectare a year.

The villagers, who receive financial benefits from forest protection, are selected by the village headman. The village headman of Phu An stated that he chose the members of the CFMB in the village based on a good health and good reputation. However, this explanation lacks a clear justification why just a few households are contracted to protect the forests for financial incentives.

According to interviews with the local households, villagers are only allowed to collect NTFPs in the natural forest and to log trees for housing. The latter, however, is only allowed after having the permission from the CPC. In Phu An village, four households are contracted to protect 120 ha of natural forests, while in Ha Bac village only two households are selected to protect 40 ha of natural forests - with the remaining 235 ha being protected by the CPC. Each household is expected to patrol and monitor the village's natural forest for at least once a month. They report their findings to the forest rangers of the $\mathrm{CPC}$, and the CFMB holds weekly meetings to discuss current affairs in forest monitoring.

Within the framework of another BSM arrangement, the commune provides poor households $15 \mathrm{~kg}$ of rice a month to support them to grow rice paddies or plant Acacia trees on former swidden plots. Because the government has prohibited shifting cultivation, villagers are stimulated by this means to stop their practices and they will be compensated for the loss of hill-rice farming. Villagers also receive subsidies on the seedlings and fertilizers to grow Acacia, rubber trees or cash crops. Besides that, the households stated during the interviews that they been trained to set-up and maintain plantation forests and intensive agriculture.

Thus, it can be concluded that only the households (six in total) who are directly engaged in forest protection receive benefits from forest protection, while the other members of the community, the majority (190 households), did not receive any benefits and are left out of the formal forest protection process. Table 3 gives a summary of the BSM in Huong Hiep. 
Table 3. Benefit sharing mechanisms in Huong Hiep, Da Krong District.

\begin{tabular}{|c|c|c|}
\hline Type of BSM & Who is Involved? & Kind of Benefits \\
\hline $\begin{array}{l}\text { Contract for protecting the natural } \\
\text { forests belonging to the villages. }\end{array}$ & A few households. & 200,000 VND per hectare a year. \\
\hline $\begin{array}{l}\text { Rice provision and support to set } \\
\text { up rice paddies, plantation forests } \\
\text { and cash crops to eradicate } \\
\text { shifting cultivation. }\end{array}$ & $\begin{array}{l}\text { Most villagers and the } \\
\text { poor in particular. }\end{array}$ & $\begin{array}{l}15 \text { kilogram of rice a month for the poor. } \\
\text { Seedlings, subsidies and training to be able to } \\
\text { plant rice paddies, Acacia, rubber and cash } \\
\text { crops. }\end{array}$ \\
\hline
\end{tabular}

\subsection{Benefit Sharing Mechanisms in Thuong Nhat, Nam Dong District}

In 2008, Nam Dong district and Thuong Nhat commune started allocating natural forestland to local communities. In order to be eligible to receive natural forestland, a community has to establish a CFMB and prepare a forest protection plan. The regulations on natural forest use and protection are then discussed with the villagers, and if the villagers agree they receives natural forestland. Forests are, preferably, allocated to the communities which make use of them. According to the commune chairman, in 2011, the DPC and CPC allocated 88.8 ha of natural forestland to village no. 6. This natural forestland forms part of the buffer zone of Bach Ma National Park (BMNP).

Village no.6 established a CFMB, with the village headman in charge, for forest patrolling and protection. This board is divided into three groups with a leader each. The CFMB also holds weekly meetings. The introduction of community forest management has, according to the CFMB, three reasons: (1) to plant native Hopea trees; (2) to have a clear demarcation between natural and plantation forests; and (3) to fulfill the demand of local communities to benefit from forest protection.

In the community forest, villagers are only allowed to collect NTFPS, and to cut trees for housing. The latter, however, can only be done after getting permission from the CPC and the Forest Protection Unit of the DPC. The CFMB, and commune chairman stated that villagers are expected to pay $20 \%$ of the market price of the collected timber to the CPC. This wood is not allowed for trade, and violators will be fined. In return, the villagers are expected to monitor the community forest on a regular basis.

Besides having a community forest, village no. 6 is receiving benefits from forest protection in BMNP. In 2012, BMNP, the CPC, and the DPC decided to set-up regulations on the use of the natural forest in BMNP for local people. As a result of Decision 126 of BMNP, a management board (MB) has been established. This MB consists of the Director of BMNP, the CPC chairman, two CPC staff, and seven heads of the villages. Three parts in the national park are now under control of the different CFMBs of the villages.

The people of village no.6 have access to 1100 ha of natural forest in BNMP. Villagers are only allowed to collect NTFPs in BMNP if they get permission from the MB. Villagers received instructions on how and when to collect NTFPs in their contracted natural forest. If villagers want to get a permission to collect NTFPs, they need to hand in a proposal to the village headman, he will send this proposal to the CPC, and the CPC chairman and the Director of BMNP decide whether the permit will be issued. After getting permission, people can harvest rattan, honey, bamboo, snails, and other NTFPs. If local people want to enter the park, they need to register with the local BMNP station. The harvesters of 
the NTFPs have to pay a fee, depending on their income and the amount and type of the collected NTFPs. Villagers are in no circumstance allowed to cut wood or collect firewood in BMNP.

The CFMB and the forest rangers of the CPC and BMNP are responsible for monitoring the natural forest belonging to BMNP. The local households proclaimed that only the forest rangers, however, are able to fine illegal exploiters of the forest. In reality, the villagers do not follow the current regulations yet. However, in the future it is expected that these regulations will be strictly enforced.

The people of village no.6 also received subsidies and loans to buy seedlings and fertilizers to set-up plantation forests and cash crops. Like Huong Hiep, they were also trained in growing and maintaining plantation forests and intensive agriculture. Starting from 2005, the villagers started planting uneatable industrial cassava - often intermixed with Acacia. Previously, cassava was grown as staple food, but this changed with the introduction of intensive agriculture.

As opposed to Huong Hiep commune, the BSM in Thuong Nhat have been much more developed. Table 4 summarizes the different types of BSM in the commune.

Table 4. Benefit sharing mechanisms in Thuong Nhat, Nam Dong District.

\begin{tabular}{lll}
\hline \multicolumn{1}{c}{ Type of BSM } & Who is Involved? & \multicolumn{1}{c}{ Type of Benefits } \\
\hline $\begin{array}{l}\text { Community forestry } \\
\text { All villagers }\end{array}$ & $\begin{array}{l}\text { Legal title or Red Book for the community forest (88.8 ha). } \\
\text { Ability to collect NTFPs. Logging for housing } \\
\text { (after permission and 20\% of the market price). }\end{array}$ \\
$\begin{array}{l}\text { Forest patrolling in Bach Ma } \\
\text { National Park }\end{array}$ & All villagers & $\begin{array}{l}\text { Ability to collect NTFPs (after permission and having paid a } \\
\text { fee depending on income and type of NTFP). Training for } \\
\text { NTFP collection. }\end{array}$ \\
$\begin{array}{l}\text { Rice provision and support to } \\
\text { set up rice paddies, plantation } \\
\text { forests and cash crops to } \\
\text { eradicate shifting cultivation. }\end{array}$ & $\begin{array}{l}\text { Most villagers and } \\
\text { the poor in particular }\end{array}$ & $\begin{array}{l}15 \text { kilogram of rice a month for the poor. Seedlings, subsidies } \\
\text { and training to be able to plant rice paddies, Acacia, rubber and } \\
\text { cash crops. }\end{array}$ \\
\hline
\end{tabular}

\subsection{Free Prior and Informed Consent (FPIC)}

Did the villagers in both communes get consulted before they participated in the BSM arrangements? The answer to this question is ambiguous and can be both positive and negative. In one way, the villagers had to follow the formal institutions, since they are the ones formulating the laws and policies. The times of semi-autonomy and customary laws and institutions have largely disappeared, and more and more villagers are integrating in mainstream Vietnamese society. However, on the other hand, the villagers of Thuong Nhat actually actively participated in community forestry and BSM in order to get a community Red Book as also mentioned in Section 5.2. In order to be eligible for a community Red Book in Thuong Nhat, a CFMB must be formed and fully operational. The CFMB should be chosen by all community members. In reality it meant that each clan within a village, with each village consisting of four to six clans, had a representative in the CFMB. Therefore, in Thuong Nhat's case, the villagers actually wanted to participate in BSM.

In Huong Hiep's case, the answer to the previous asked question should be negative. Only a few elite households were able to participate in BSM. The majority of the villagers were largely unaware of the BSM arrangements in forest protection, or they acknowledged that they didn't get any benefits. One 
villagers of Phu An villager, however, stated: "If our village would get a better infrastructure and schools for our children, I would be happy to help patrol the natural forests". Also, throughout other interviews and focus group discussions, there was willingness from the villagers to receive a community forest Red Book and to participate in BSM. The community forest rangers stated that the commune expected Huong Hiep commune to receive community Red Books in 2013. However, since our last visit to Huong Hiep (July 2014), this had yet to happen.

The villagers of both communes perceived the Red Book to be important. The general conception was that if villagers would plant tree species in their community forests, they would later be eligible to selectively log some of the planted trees for selling and housing.

\subsection{Natural, Physical Capital and Financial Capital}

Natural, physical and financial capital are the interconnected tangible assets of a person's livelihood. How do current BSM arrangements affect these tangible assets of the communities?

Villagers in both communes are restricted in entering and exploiting their natural capital - the natural forests. The freedom of access is closely related to the enforcement of rules and regulations, and the quality of the forests. In Huong Hiep, some households are still able to conduct shifting cultivation, because the local authorities seem to have less capacity in preventing people from doing it. However, in Thuong Nhat, local authorities, having more capacity and enforcement power, have been able to ban shifting cultivation in the commune more effectively. None of the interviewed households in Thuong Nhat said that they still practiced shifting cultivation, as opposed to the interviewed households in Huong Hiep who openly admitted to still conduct shifting cultivation.

Local people have least access to the natural forests of BMNP. They even have to ask for permission from the Park to be able to enter the forest. Reasons why people have restricted access to BMNP has a lot to do with the fact that the natural forest of BMNP is much richer than the community forest, which is of poor quality. Local households of village no. 6 all agreed in the focus group discussion that the availability and quality of NTFPs and other forest products in the community forest is significantly less than the natural forest in BMNP (See Table 5).

In exchange for having less access to their natural capital, villagers receive support from the authorities to plant rubber trees, Acacia, cash crops and wet-rice. According to the village headmen, most villagers own plantation forestland, and many villagers' livelihood depend on it. Physical capital, such as seedlings, fertilizers, and equipment, has been made available to the villagers through subsidies and loans (financial capital). While previously, the villagers of Thuong Nhat could not legally collect NTFPs in BMNP, they are now able to do so. As can be seen in Table 5, most NTFPs are for selling. Therefore, the current benefits legally allow the villagers to have a higher income.

In order to combat food insecurity, poor villagers receive rice and support to plant wet-rice. However, it remains a question whether handing out rice is sustainable. It also remains a question whether wet-rice cultivation can make up for the loss of hill-rice cultivation. Some villagers in Huong Hiep are still forced to practice shifting cultivation for subsistence purposes. Also in Thuong Nhat, the villagers stated that they were not able to cultivate enough rice for subsistence. In Thuong Nhat, however, the villagers are able to buy rice from their income derived from cash crops and plantation forests. However, the poor, who often have little plantation forestland or the ability to grow cash crops, are more vulnerable to food 
insecurity. At the same time, both communities in Thuong Nhat and Huong Hiep are quite vulnerable to external shocks such as natural hazards - e.g., storms in 2006 and 2009 destroyed most of the plantation forests of the villagers in Thuong Nhat.

Table 5. Differences between the community forest of village no. 6 and the natural forest in Bach Ma National Park (BMNP). Source: Focus group discussion with households of Village No. 6, Thuong Nhat commune.

\begin{tabular}{|c|c|c|c|}
\hline \multirow[t]{2}{*}{ Type of Forest Product } & \multicolumn{2}{|c|}{$\begin{array}{c}\text { Availability } \\
(\bullet=\text { little }, \bullet=\text { normal, } \bullet \bullet=\text { very } \text { much })\end{array}$} & \multirow{2}{*}{$\begin{array}{l}\text { For Consumption or Selling } \\
\text { (VND) }\end{array}$} \\
\hline & Community Forest & National Park & \\
\hline Honey & $\bullet$ & $\bullet$ & Sell: $200,000 / 650 \mathrm{~mL}$. \\
\hline Rattan & $\bullet$ & $\bullet \bullet$ & Sell: $3700 / \mathrm{kg}$ \\
\hline Bamboo shoots & (half star) & $\bullet$ & Sell + consumption: $2500 / \mathrm{kg}$ \\
\hline Snail & None & œ•• & Sell: $9000 / \mathrm{kg}$ \\
\hline Wild pig & $\bullet$ & œ•• & Sell: $100,000 / \mathrm{kg}$ \\
\hline Hat-leaves & $\bullet$ & 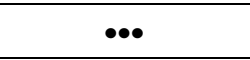 & Sell: $10,000 / 100$ leaves \\
\hline Malva nuts & - & ..• & Sell: $70,000 / \mathrm{kg}$ \\
\hline Firewood & œ•• & Not allowed & Consumption \\
\hline Medicine & $\cdot$ & Don't know & Sell + consumption \\
\hline Frog & None & ••• & Sell + consumption: $100,000 / \mathrm{kg}$ \\
\hline Fish & None & ..• & Sell + consumption: $70,000 / \mathrm{kg}$ \\
\hline Mushroom & $\bullet$ & $\bullet$ & Sell: $200,000 / \mathrm{kg}$ (dried) \\
\hline Animal & - & $\bullet \bullet$ & $\begin{array}{l}\text { Sell + consumption: } 50,000 / \mathrm{kg} \\
\text { (inside the village) }\end{array}$ \\
\hline Wood & $\bullet$ & Not allowed & Consumption (e.g., housing) \\
\hline
\end{tabular}

The biggest flaw of BSM in Huong Hiep is that only elite households are able to receive benefits from forest protection. This led to a growing discrepancy in income between the households contracted to protect the natural forests, and the other villagers. Therefore, BSM in Huong Hiep actually contributed to a growing economic inequality between the households. This resembles the study of To et al. [4], in which primarily elite households were receiving the benefits from PES, because of political and economic factors.

\subsection{Human, Social and Cultural Capital}

Human, social and cultural capital are the interconnected intangible assets of a person's livelihood. For many indigenous peoples, the natural environment forms an essential part of their culture and social life. Customary knowledge, forest management arrangements, boundaries, institutions, and rules, laws and punishments, are closely intertwined with a community's beliefs, culture, social and political systems. Furthermore, customary knowledge and practices are often compatible with other modes of knowledge, such as scientific knowledge. Customary forest management systems are often spatially expressed through forest classification systems, such as sacred forests and ghost forests [37-39].

In terms of human capital, the villagers stated during the interviews and focus group discussions that they have been trained on how to plant and maintain plantation forests, how and when to collect NTFPS, 
how to protect and monitor the natural forest, and in the future, they will most likely receive training on how to measure the carbon stocks in their forests. However, in the formal forest management process, customary knowledge seems not to be utilized. In banning shifting cultivation, knowledge and institutions arrangements related to shifting cultivation systems will also be most likely lost in the near future.

The same counts for social capital. Villagers expanded their network within the formal circles. They also learned how to get access to loans, credit and subsidies. However, there is a real risk that poor households are not able to expand their social network, and that they will be excluded in the BSM process. In Huong Hiep, a lack of having a broad social network resulted in a situation in which only a few households could financially benefit from forest protection.

Another key element of social capital is customary institutions and actors. Customary rules, laws and punishments are still enforced in Huong Hiep, because the local authorities have a lesser grip on its communities. In Thuong Nhat, on the other hand, the status of the village patriarch, the traditional leader, and customary institutions has been reduced to a ceremonial one. One villager of Thuong Nhat stated: "The village patriarch teaches us about how to conduct weddings, festivals and burials, but the village headman tells us how to make use of the forest". In the formal BSM process, for both communes, customary institutions and actors, such the village patriarchs, are hardly involved.

It remains a question how current BSM arrangements will affect people's cultural capital. In Huong Hiep, both villages still have ghost forests. In a ghost forest, villagers are burying their dead, and villagers are prohibited to exploit or even enter the forest. These forests are often primary forests rich in biodiversity. Until today, villagers will be punished by the patriarch if they exploit the ghost forest, because it is believed that the whole community will be collectively punished if this rule is violated. If a violator is caught chopping trees in the ghost forest, he has to pay a fine to both the village patriarch and the formal institutions. On the other hand, Huong Hiep did not really include these customary forest classifications in their forest protection plans. In Thuong Nhat, villagers stated that they do not have a ghost forest anymore. The existence of customary forest classification systems seems to be related to the level of integration of local villagers in the formal forest management and BSM arrangements.

In conclusion, the communities are gaining from human and social capital agglomeration. They know more about plantation forests, and "scientific" ways of managing a natural forest and collecting NTFPs. In the long term however current arrangement could deteriorate their customary knowledge, social and cultural arrangements. Current research on REDD+ hardly pays attention to these factors yet, but it has just been addressed by some studies [32,33].

\section{Discussion}

BSM and REDD+ affect the available capital of local communities in several ways. In this study the sustainable livelihoods approach has been applied to two communes in Vietnam. The BSM arrangements in the communes have affected the local communities on several dimensions. The sustainable livelihoods approach acknowledges that trade-offs are to be made [10]. For example, while villagers received fewer benefits from their natural capital, they gained in terms of having more financial capital. Creating social safeguards for REDD+ requires a need to acknowledge the complex and interconnected relationship of the different types of capital. 
Table 6. Sustainable livelihoods framework for REDD+ and BSM.

\begin{tabular}{|c|c|c|c|c|c|c|}
\hline Types of Capital & Natural & Physical & Financial & Social & Human & Cultural \\
\hline Natural & $\begin{array}{l}\text { Natural resource stocks; } \\
\text { forests; water; NTFPs; } \\
\text { carbon stocks. }\end{array}$ & & & & & \\
\hline Physical & $\begin{array}{l}\text { Plantation trees; dams and } \\
\text { streams; natural resources } \\
\text { necessary to produce physical } \\
\text { capital (input and output). }\end{array}$ & $\begin{array}{l}\text { Seedlings, fertilizers, } \\
\text { equipment; food; wood. }\end{array}$ & & & & \\
\hline Financial & $\begin{array}{l}\text { Ability to buy and sell land; } \\
\text { using land as collateral to get } \\
\text { access to credits and loans. }\end{array}$ & $\begin{array}{l}\text { Ability to buy food; } \\
\text { ability to buy equipment, } \\
\text { seedlings and fertilizers. }\end{array}$ & $\begin{array}{l}\text { Credit; loans; } \\
\text { subsidies; } \\
\text { development aid. }\end{array}$ & & & \\
\hline Social & $\begin{array}{l}\text { Social rules, norms and laws } \\
\text { on how to manage the natural } \\
\text { capital; knowing the right } \\
\text { people in having legal } \\
\text { land titles. }\end{array}$ & $\begin{array}{l}\text { Social rules, norms and } \\
\text { laws on how to utilize, } \\
\text { share and produce the } \\
\text { physical capital; social } \\
\text { networks for getting } \\
\text { access to physical capital. }\end{array}$ & $\begin{array}{l}\text { Customary and } \\
\text { formal taxes, fines } \\
\text { and punishments; } \\
\text { social networks for } \\
\text { accessing loans } \\
\text { and credit. }\end{array}$ & $\begin{array}{l}\text { Customary and formal } \\
\text { institutions; trust; } \\
\text { social cohesion; social } \\
\text { rules; customary laws; } \\
\text { social networks. }\end{array}$ & & \\
\hline Human & $\begin{array}{l}\text { Technological, scientific and } \\
\text { customary knowledge about } \\
\text { forests; knowledge to plant } \\
\text { plantation forests and crops. }\end{array}$ & $\begin{array}{l}\text { Knowledge of having } \\
\text { access to physical capital; } \\
\text { knowledge of being able } \\
\text { to operate or use physical } \\
\text { capital; medicine and } \\
\text { health products. }\end{array}$ & $\begin{array}{l}\text { Knowledge of having } \\
\text { access to credits, } \\
\text { loans, subsidies or } \\
\text { development aid; } \\
\text { access to health care } \\
\text { and medical services. }\end{array}$ & $\begin{array}{l}\text { Knowledge about } \\
\text { customary and formal } \\
\text { institutions; knowledge } \\
\text { about formal and } \\
\text { customary regulations, } \\
\text { rules and laws. }\end{array}$ & $\begin{array}{l}\text { Customary } \\
\text { knowledge; } \\
\text { technological } \\
\text { knowledge; } \\
\text { scientific knowledge; } \\
\text { manpower; health. }\end{array}$ & \\
\hline Cultural & $\begin{array}{l}\text { Sacred forests; watershed } \\
\text { forests; spirit and ghosts } \\
\text { forests; other natural resources } \\
\text { which are important for the } \\
\text { culture; such as holy animals; } \\
\text { rocks; tree species; etc. }\end{array}$ & $\begin{array}{l}\text { Physical capital to be } \\
\text { able to conduct cultural } \\
\text { relevant activities, } \\
\text { such as having musical } \\
\text { instruments; communal } \\
\text { houses; and so on. }\end{array}$ & $\begin{array}{l}\text { Financial means to be } \\
\text { able to conduct } \\
\text { cultural relevant } \\
\text { activities, such as } \\
\text { festivals; weddings; } \\
\text { funerals; etc. }\end{array}$ & $\begin{array}{l}\text { Social resources and } \\
\text { networks which help } \\
\text { preserving the culture; } \\
\text { customary laws and } \\
\text { institutions relevant to } \\
\text { preserving the culture. }\end{array}$ & $\begin{array}{l}\text { Customary } \\
\text { knowledge forms a } \\
\text { part of the culture; } \\
\text { knowledge related to } \\
\text { customs, religious } \\
\text { practice, etc. }\end{array}$ & $\begin{array}{l}\text { Religion; cultural } \\
\text { customs; language; } \\
\text { identity; dispositions. }\end{array}$ \\
\hline
\end{tabular}


Table 6 presents a sustainable livelihood framework for REDD+ and BSM implementation. This framework is not all encompassing, but it will help policy makers and scholars to identify the complex process of livelihood development. Within the REDD+ debate the different types of capital have been acknowledged but very rarely have they been connected in a holistic manner. However, connecting these different types of capital, could not only result in doing "no-harm", but it could actually contribute to livelihood improvement and providing co-benefits. Three cases will showcase how the sustainable livelihood framework could be utilized in creating stronger social safeguards. These cases include: (1) how to cope with external unforeseeable events caused or partly caused by climate change; (2) how co-benefits besides carbon credits could be provided; and (3) how REDD+ or BSM could incorporate customary institutions and laws. This section ends with specific recommendations on REDD+ implementation in Vietnam for creating social safeguards.

\subsection{Coping with External Shocks}

Many households in the research villages have been affected by unforeseeable catastrophic events such as floods and storms. These events did not only damage the villages' infrastructure, but also damaged the plantation forests, wet-rice fields, home gardens, and newly planted natural forests. With having the plantation forests destroyed, many villagers struggled to pay back their loans which they initially got to be able to plant Acacia or rubber. This caused them to borrow more money, and made them more indebted and, therefore, more vulnerable to external shocks. Some (poorer) households were even forced to sell parts of their forestland, since they could not cope with their losses. A part of these households became land laborers on their previously owned forestland.

The above mentioned case shows the usefulness of approaching the different types of capital in a holistic manner. External shocks did not only damage the physical and natural capital of the villagers, but it also directly affected their financial capital, making the poor in particular most vulnerable to unforeseeable and external shocks in the future. Within the REDD+ context it is essential, especially with an increase of climate change related disasters, to not only strengthen the natural capital to mitigate disasters (i.e., watershed protection forests), but also the physical capital of the communities (irrigation systems, equipment to nurture plantation forests, and so on), as well as the financial capital (such as an insurance system or a disaster recovery fund), social capital (allowing people to have access to funding and loans) and human capital (teaching villagers to make their forests more resilient). Making the communities more resilient to external shocks involves all types of capital. Solely focusing on carbon conservation will not be sufficient to deal with external shocks.

\subsection{Co-Benefits from REDD+}

The issue of how REDD+ is going to be funded remains a question. It is not clear whether REDD+ projects will be funded by international or voluntary carbon markets or by international development assistance. It also remains a question whether REDD+ should be approached as a programme or as stand-alone projects. The scope of REDD+ is also not decided: Should it be bilateral or multilateral cooperation, and on subnational or national scales? It also remains unclear how the private and public sectors will interact, and who is willing to invest in REDD+ [40]. The role of market-based instruments in REDD+ remains unclear. Therefore, even if Vietnam could clarify the carbon rights of landowners, it 
will still remain a question whether access to the carbon market will really provide benefits to the new carbon right owners.

Verified carbon credits, which are a type of natural capital, could be one of the benefits of REDD+. In our research we have shown that financial capital actually played a marginal role in benefit sharing mechanisms. People received a fee for protecting the forests, but this fee was merely used to cover the costs of patrolling the forests. Other benefits, however, were more important to the villagers. The villagers in Thuong Nhat commune were able to legally collect NTFPs. This allowed them to make use of the natural forests, without fearing for their products to be confiscated by the district's forest patrollers. Other benefits included the provision of physical, financial and human capital from the local government to the villagers to be able to plant and nurture plantation forests. This livelihood strategy shift to plantation forests made the villagers less dependent on the natural forests. Within the REDD+ context, plantation forests could be utilized to prevent deforestation and forest degradation. Having Red Books, both on household and community level, has also been recognized as an important benefit. Local people are willing to invest in their land, because now they can focus on long-term benefits as opposed to the short term benefits of forest exploitation. Finally, protecting the natural forests could secure water supply to the villagers and mitigate natural disasters, as mentioned in the previous section. Therefore, the co-benefits of REDD+ are not only natural capital related, but also deal with all other types of capital, ranging from having loans to establish a plantation forest to acquiring knowledge about the role of natural forests in protecting the planation forests.

\subsection{Customary Arrangements and REDD+}

Both research areas still had customary forest management arrangements and institutions. Whereas in Huong Hiep the local government cooperated more with customary institutions than in Thuong Nhat, the role of these customary arrangements and institutions in forest protection in both communes is still moderate to big. Customary arrangements and institutions encompass all the different types of capital. This ranges from customary ecological knowledge to customary fines and punishment, and from cultural aspects, such as songs and stories related to the forests, to customary livelihood strategies such as shifting cultivation. If REDD+ is to be expected to respect indigenous people's rights and 'true' FPIC, the holistic nature of customary arrangements should not be overseen.

So far, there has been little debate about how customary arrangements could be integrated into REDD+. In our research we have shown that, for example, in Huong Hiep commune, local people still actively preserve their ghost forests. Within a REDD + scheme these ghost forests could still be preserved in a customary manner, while at the same time communities could receive additional benefits from continuing their preservation efforts through REDD+. FPIC is another relevant aspect which needs to include customary institutions. Customary institutions still make many land use and non-land use related decisions within the villages. In order for FPIC to be more successful, it is highly recommendable to operate within the villages' existing social and institutional structures. However, this is proven to be problematic, since REDD+ primarily operates through formal institutions. Both UN-REDD and the FCPF mainly operate on national scales with States as their main partners. 


\subsection{Recommendations for Creating Social Safeguards for REDD+ in Vietnam}

Establishing social safeguards in REDD+ involves many different types of capital as has been seen in this study. In order to strengthen the social safeguards in REDD+, it is necessary to approach sustainable livelihoods in a holistic manner. Below, we provide some recommendations for each type of capital, and for the Vietnamese context in particular.

- Natural capital: Securing land tenure and carbon rights are important first steps in REDD+. Preferably, forestland in a REDD + scheme should be allocated to communities instead of households. The Civil Code of Vietnam, however, does not recognize the community as a legal unit. Under the Forest Protection and Development Law, a community is allowed to receive land-the community Red Book. Holding this Red Book, however, does not allow the community to enter into land-based economic transactions-e.g., REDD+ projects, land conversion, etc. They are only allowed to protect the allocated forestland [41]. Therefore, in order for REDD+ to succeed, the Civil Code need to recognize communities as legal entities.

Vietnam is also still lacking a legal framework on carbon-trade. It is not clear who owns the carbon-rights, and therefore it is difficult to say whether local communities can really benefit from REDD+. Clear mechanisms need to be developed which ensure local people that they own the carbon rights. It is now not clear how local households and communities will benefit from REDD+.

- Physical capital: All the different uses of the natural resources need to be negotiated, whether it is about shifting cultivation, collecting NTFPs, setting up plantation forests, or engaging in intensive agriculture. REDD+ needs to ensure that it will not threaten the food security of the local communities. It also needs to make sure that local communities are not made more vulnerable to external shocks and changes. In terms of community carbon measuring, local communities need to be equipped with the right equipment. Favorably, communities should have GPS equipment to demarcate their customary boundaries.

- Financial capital: Mechanisms need to be implemented which ensure that all the households receive the financial benefits of REDD + in an equal and transparent manner. Furthermore, in order for REDD+ to succeed it should at least exceed the opportunity costs of forest users, which is decided by profits foregone and transactions costs [5].

- Human capital: FPIC deals with informing villagers about the benefits, risks and rationale of REDD+. Transferring this knowledge is crucial for communities to be able to decide whether they want to engage in a REDD+ project or not. It should also be explored whether customary forest management arrangements and REDD+ could be incorporated to avoid the deterioration of the human capital of the communities.

- Social and cultural capital: The FPIC process could be more successful if REDD+ implementers cooperate with both formal and customary institutions. REDD+ should not disempower customary institutions in favor of the formal counterparts. Furthermore, ways should be explored to connect traditional forest classification systems with REDD + schemes. Sacred forests are often rich in biodiversity and carbon stocks [37]. A win-win situation could be created if REDD+ implementer are sensitive of customary forest classifications and boundaries. 


\section{Conclusions}

The villagers in Huong Hiep and Thuong Nhat commune have been affected by BSM in various ways. In Huong Hiep, there is no real BSM, the local government had just chosen an elite group of villagers to protect the forests for a fee. In Thuong Nhat, on the other hand, the villagers owned a community forests through a Red Book, and the whole village was involved in forest patrolling. Besides that, Bach Ma National Park also allowed villagers to have access to the Park and to be able to collect NTFPs, in exchange for villagers to patrol and protect the Park. However, the following main conclusions related to the impact of BSM, from a sustainable livelihoods approach could be drawn.

First of all, the direct financial aspects (i.e., fees for forest protection) of the BSM arrangements turned out to play a marginal role. These fees were mainly used to cover the expenses of patrolling the forests. However, the co-benefits turned out to be more important. Villagers in Thuong Nhat could legally collect NTFPs and sell them on the market. The villagers in Thuong Nhat also received a community Red Book, allowing them to reap the long-term benefits of their conservation and reforestation efforts. Furthermore, the villagers in both research areas received loans, material and training to be able to plant plantation forests and cash crops.

On the other hand, some villagers faced food insecurity, since they were not allowed to conduct shifting cultivation anymore. Even though they were given rice, they were still more vulnerable to food insecurity. The villagers were also more vulnerable to natural hazards, since they invested a lot of money in establishing plantation forests. However, past natural disasters have shown that plantation forests in the area could easily be destroyed. The villagers are now, unlike in the past, more vulnerable to external shocks. Finally, the local government tended to eliminate customary forest arrangements, such as shifting cultivation or the maintenance of ghost forests. BSM arrangements were also implemented through the formal institutions, represented by the village headman, whereas the village patriarch saw his role diminishing to merely a ceremonial one.

REDD + has the potential to be the new environmental paradigm on conservation and livelihood improvement. In order to create a win-win situation, it is essential that livelihood improvement and development should be seen in a holistic, interconnected, dynamic and multi-factorial way. As our study has shown, BSM affected the communities on different dimensions, expressed as different types of capital. The main discussion about REDD+ is whether it should do "no-harm" or whether it should be pro-poor. It could also be that REDD+ could do both harm and be pro-poor. The question remains whether a trade-off would be sufficient to outweigh the negative aspects. It is this very reason why FPIC plays a central role in our adapted sustainable livelihoods model. It should be up to the communities to decide whether the negative effects of REDD + outweigh the positive ones or vice versa.

REDD+ is, on the local level, more complex than theoretical discussions tend to display. Lessons learned from BSM in Vietnam have shown that the five types of capital, representing the local context, need to be taken into account in a holistic manner in order to understand the true dynamics of the implemented programme and to be able to create social safeguards. If REDD+ does not take the local context sufficiently into account, it might be destined just to remain a theoretical concept. 


\section{Acknowledgments}

This research has been supported by the Worldwide Universities Network (WUN) Research Development Fund. The authors offer their sincere thanks to Thanh Liem Dang, Tore Langhelle, Soojin Kim, Inoguchi Akiko, To Xuan Phuc, Dominick Spracklen, the anonymous reviewers, and Nophea Sasaki. Furthermore, they thank the people of Thuong Nhat and Huong Hiep commune. Last but not least, they would like to thank the staff and student-helpers of Hue University of Agriculture and Forestry, Ha van Thien, Phan Thi Kim Tu, and Pham Huu Minh.

\section{Author Contributions}

Mucahid Mustafa Bayrak is a $\mathrm{PhD}$ candidate and is currently doing research on REDD+ in Vietnam. He conducted the research and analyzed the data. Tran Nam Tu is the local partner in Vietnam and helped conducting the research, as well as analyzing the data. Lawal Mohammed Marafa is Mucahid Mustafa Bayrak's supervisor and helped him to conceptualize and analyze the study.

\section{Conflicts of Interest}

The authors declare no conflict of interest.

\section{References}

1. Campbell, B.M. Beyond Copenhagen: REDD+, agriculture, adaptation strategies and poverty. Glob. Environ. Chang. 2009, 19, 397-399.

2. Brown, D.; Seymour, F.; Peskett, L. How do we achieve REDD co-benefits and avoid doing harm? In Moving ahead with REDD: Issues, Options and Implications; Angelsen, A., Ed.; Center for International Forestry Research: Bogor, Indonesia, 2008; pp. 107-118.

3. To, P.X.; O’Sullivan, R.; Olander, J.; Hawkins, S.; Hung, P.Q.; Kitamura, N. REDD+ in Vietnam: Integrating National and Subnational Approaches; Forest Trends Association and Climate Focus: Washington, DC, USA, 2012.

4. To, P.X.; Dressler, W.H.; Mahanty, S.; Pham, T.T.; Zingerli, C. The prospects for payment for ecosystem services (PES) in Vietnam: A look at three payment schemes. Hum. Ecol. 2012, 40, 237-249.

5. Wunder, S. Payment for environmental services and the poor: Concepts and preliminary evidence. Environ. Dev. Econ. 2008, 13, 279-297.

6. Griffiths, T.; Martone, F. Seeing “REDD”? Forests, Climate Change Mitigation and the Rights of Indigenous Peoples and Local Communities; Update for Poznan (UNFCCC COP 14); Forest Peoples Programme: Moreton-in-Marsh, UK, 2009.

7. Van Noordwijk, M.; Leimona, B. Principles for fairness and efficiency in enhancing environmental services in Asia: Payments, compensation, or co-investment? Ecol. Soc. 2010, 15, ART.17.

8. Mahanty, S.; Suich, H.; Tacconi, L. Access and benefits in payments for environmental services and implications for REDD+: Lessons from seven PES schemes. Land Use Policy 2013, 31, 38-47. 
9. Tacconi, L.; Mahanty, S.; Suich, H. The livelihood impacts of payments for environmental services and implications for REDD+. Soc. Nat. Resour. 2013, 26, 733-744.

10. Chambers, R.; Conway, G.R Sustainable Rural Livelihoods: Practical Concepts for the 21st Century, IDS Discussion Paper 296; Institute of Development Studies at the University of Sussex: Brighton, UK, 1991.

11. Agrawal, A.; Nepstad, D.; Chhatre, A. Reducing emissions from deforestation and forest degradation. Ann. Rev. Environ. Resour. 2011, 36, 373-396.

12. UN-REDD. The UN-REDD Programme and the World Bank's Forest Carbon Partnership Facility. Newsletter Issue \# 1. 1 August 2009. Available online: http://www.un-redd.org/NewsCentre/ Newsletterhome/1Feature2/tabid/1588/language/en-US/Default.aspx/ (accessed on 31 July 2014).

13. UN-REDD. UN-REDD Vietnam Phase II Multi-Partner Trust Fund: Terms of Reference. Available online: http://mptf.undp.org/factsheet/fund/VNM00/ (accessed on 10 May 2014).

14. Cypher, J.M.; Dietz, J.L. The Process of Economic Development; Routledge: London, UK, 2009.

15. Scoones, I. Sustainable Rural Livelihoods: A Framework for Analysis; IDS Working Paper 72; Institute of Development Studies at the University of Sussex: Brighton, UK, 1998.

16. Sen, A. Commodities and Capabilities; Elsevier Science: Amsterdam, The Netherlands, 1985.

17. Zoomers, A. Rural livelihoods. In The Companion to Development Studies; Desai, V., Potter, R.B., Eds.; Hoddor: London, UK, 2008; pp. 147-151.

18. Serrat, O. The Sustainable Livelihoods Approach; Asian Development Bank: Washington, DC, USA, 2008.

19. Levitt, P.; Namba-Nieves, D. Social remittances revisited. J. Ethn. Migr. Stud. 2011, 37, 1-22.

20. Bebbington, A. Social capital and development. In The Companion to Development Studies; Desai, V., Potter, R.B., Eds.; Hoddor: London, UK, 2008; pp. 132-136.

21. The International Fund for Agricultural Development (IFAD). The Sustainable Livelihoods Approach. Available online: http://www.ifad.org/sla/ (accessed on 10 May 2014).

22. UN-REDD Programme; The Forest Carbon Partnership Facility. Guidelines on Stakeholder Engagement in REDD+ Readiness with a Focus on the Participation of Indigenous Peoples and Other Forest-Dependent Communities. Available online: https://www.forestcarbonpartnership.org/ sites/fcp/files/2013/May2013/Guidelines\%20on\%20Stakeholder\%20Engagement\%20April\%2020 $\% 202012 \% 20$ (revision\%20of\%20March\%2025th\%20version).pdf/ (accessed on 10 May 2014).

23. Leggett, M.; Lovell, H. Community perceptions of REDD+: A case study from Papua New Guinea. Clim. Policy 2012, 12, 115-134.

24. Bolin, A.; Tassa, D.T. Exploring climate justice for forest communities engaging in REDD+: Experiences from Tanzania. Forum Dev. Stud. 2012, 39, 5-29.

25. Wertz-Kanounnikoff, S. Global REDD negotiation: Update and key issues. In REDD, Forest Governance and Rural Livelihoods: The Emerging Agenda; Springate-Baginski, O., Wollenberg, E., Eds.; Center for International Forestry Research: Bogor, Indonesia, 2010; pp. 21-30.

26. Phelps, J.; Webb, E.L.; Agrawal. A. Does REDD+ threaten to recentralize forest governance? Science 2010, 328, 312-313.

27. Hayes, T.; Persha, L. Nesting local forestry initiatives: Revisiting community forest management in a REDD+ world. For. Policy Econ. 2010, 12, 545-553. 
28. Larson, A.M. Forest tenure reform in the age of climate change: Lessons for REDD+. Global Environ Change. 2011, 21, 540-549.

29. Corbera, E. Problematizing REDD + as an experiment in payments for ecosystem services. Curr. Opin. Environ. Sustain. 2012, 4, 612-619.

30. Huettner, M. Risks and opportunities of REDD+ implementation for environmental integrity and socio-economic compatibility. Environ. Sci. Policy 2012, 15, 4-12.

31. Ghazoul J.; Butler, R.A.; Mateo-Vega, J.; Koh, L.P. REDD: A reckoning of environment and development implications. Trends Ecol. Evol. 2010, 25, 396-402.

32. Anderson, N. REDDy or not? The effects on Indigenous Peoples in Brazil of a global mechanism for reducing emissions from deforestation and degradation. J. Sustain. Dev. 2009, 2, 18-28.

33. Asia Indigenous Peoples Pact (AIPP). REDD+ Implementation in Asia and the Concerns of Indigenous Peoples; Asia Indigenous Peoples Pact: Chiang Mai, Thailand, 2010.

34. Nguyen, T.Q. Trends in Forest Ownership, Forest Resources Tenure and Institutional Arrangements: Are They Contributing to Better Forest Management and Poverty Reduction? Case Study Vietnam; Forestry Policy and Institutions Working Paper No 14.; Food and Agriculture Organization (FAO): Rome, Italy, 2006.

35. Sunderlin, W.D.; Ba, H.T. Poverty Alleviation and Forests in Vietnam; Center for International Forestry Research: Bogor, Indonesia, 2005.

36. Tu, T.N.; Burgers, P. Decentralized forest governance in central Vietnam. In Moving forward with Forest Governance; Broekhoven, G., Savenije, H., von Scheliha, S., Eds.; Tropenbos International: Wageninge, The Netherlands, 2012; pp. 240-250.

37. Van Leeuwen, L. Approaches of Successful Merging of Indigenous Forest-Relate Knowledge with Formal Forest Management: How Can Modern Science and Traditions Join Hands for Sustainable Forest Management? National Reference Centre for Nature Management, Ministry of Agriculture, Nature Management and Fisheries: Wageningen, The Netherlands, 1998.

38. Berkes, F. Sacred Ecology; Routledge: New York, NY, USA, 2008.

39. Bayrak, M.M.; Tu, T.N.; Burgers, P. Restructuring space in the name of development: The sociocultural impact of the forest land allocation program on the indigenous Co Tu people in central Vietnam. J. Polit. Ecol. 2013, 20, 37-52.

40. Romero, M.Z.; Trærup, S.; Wieben, E.; Møller, L.R.; Koch, A. Economics of Forest and Forest Carbon Projects. Translating Lessons Learned into National REDD+Implementation; Report for United Nations Environment Programme (UNEP) Riso Centre; UNEP and UN-REDD: Nairobi, Kenya, 2013.

41. To Xuan Phuc (Forest Trends Association, Washington, DC, USA). Personal communication, 2013.

(C) 2014 by the authors; licensee MDPI, Basel, Switzerland. This article is an open access article distributed under the terms and conditions of the Creative Commons Attribution license (http://creativecommons.org/licenses/by/3.0/). 